\title{
Effects of Curcumin Supplemented Diet on Growth and Non-Specific Immune Parameters of Cirrhinus mrigala against Edwardsiella tarda Infection
}

\author{
Tasok Leya*, Ram Prakash Raman, Prem Prakash Srivastava, Kundan Kumar, Irshad \\ Ahmad, Adnan Hussain Gora, Nalini Poojary, Saurav Kumar and Showkat Ahmad Dar
}

ICAR- Central Institute of Fisheries Education, Mumbai-400 061, India

*Corresponding author

\section{A B S T R A C T}

The present research was conducted to evaluate the effect of curcumin supplement diet (CSD) on non-specific immunity, growth and disease resistance against Edwardsiella

\section{Keywords}

Curcumin, Nonspecific Immunity, Growth

performance, Lethal dose, Relative percentage survival, Edwardsiella tarda.

Article Info

Accepted:

17 July 2017

Available Online:

10 September 2017 tarda infection in Cirrhinus mrigala. Fishes were fed with formulated diet containing curcumin in different graded levels as control (C) $(0.00 \%), \mathrm{T} 1(0.25 \%)$, T2 $(0.5 \%)$, T3 $(1.0 \%)$, T4 $(1.5 \%)$, and T5 $(2.0 \%)$ for 45 days. Treatments were maintained in triplicate and each tank was stocked with 20 fingerlings $(10.5 \mathrm{~g} \pm 1.4)$. Fishes were challenged with a virulent strain of $E$. tarda after 45 days of feeding and relative percentage survival was recorded over 14 days post challenge. The percentage weight gain (PWG), feed efficiency ratio (FER), feed conversion ratio (FCR), specific growth rate (SGR), protein efficiency ratio (PER) of fishes fed with curcumin enriched diet were found to be significantly ( $\mathrm{p}<$ 0.05 ) better than the control group. Dietary curcumin at the level of $1.5 \%$ (T4) showed significantly $(\mathrm{p}<0.05)$ higher RPS $(62.5 \%)$ against $E$. tarda infection than control. Blood and serum samples were collected for non-specific immune parameters on $0,15,30$, and 45 days interval and growth performance was evaluated at every 15 days period of the experiment. The results suggest that fishes feed with curcumin enriched diet (1-1.5\%) showed significantly $(\mathrm{p}<0.05)$ higher total immunoglobulin, serum protein, serum albumin, Immunoglobulin, respiratory burst activity and myeloperoxidase activity. Hence, this study revealed that CSD has a potential stimulatory effect on non-specific immunity along with improved growth performance and increased disease resistance against E. tarda infection in C. mrigala.

\section{Introduction}

Over the past few decades, aquaculture production has increased significantly due to the intensification of culture practices. However, disease outbreaks are increasingly at the same time and are being recognized as a potential constraint on aquaculture production trade thus causes massive economic losses to the farmers. The most common strategy to combat diseases in aquaculture is the use of antibiotics; however, the use of antibiotic for controlling diseases has been widely criticized for their negative impacts (Rijkers et al., 1980; Grondel et al., 1987; Ellis, 1988). In order to reduce the risk of disease, the level of resistance to infection in the cultured organisms should be increased by the use of better feeds, vaccines, and immunostimulants and by selective breeding for higher disease resistance (Raa et al., 1992). Immunostimulation is considered as a 
promising alternative therapy to antibiotics because of their broad spectrum nature, cost effectiveness, and eco-friendly disease preventive measure. The immunostimulant can be derivative of biological agents and synthetic drugs. Among the biological agents, plant derivatives are most commonly used for disease treatment because it is economical and versatile in nature.

Curcumin, derived from the rhizome of turmeric plant (Curcuma longa), is one of the best-studied natural compounds. There are several reports indicating a wide range of pharmacological activities of turmeric reported as anti-microbial (Negi et al., 1999), antitumour (Ozaki et al., 2000), anti-allergic (Yano et al., 2000), anti-inflammatory (Surh et al., 2001) and antioxidant (Masuda et al., 2002). Most of these effects were observed in studies conducted earlier in mammals or in cell lines.

Edwardsiella sp. are the most significant disease-causing microbes (Mohanty and Sahoo, 2007) which causes edwardsiellosis leading to mass mortality in freshwater and marine fish (Ewing et al., 1965) with extensive skin lesions, affecting internal organs such as liver, kidney, spleen and muscle (Nucci et al., 2002) and also affects human beings by causing gastroenteritis and generalized infections mainly occurs among individuals with impaired immune systems (Plumb, 1994; Thune et al., 1993; Rao et al., 2001). Therefore, the objective of the present study was to evaluate the effect of curcuminsupplemented diet on the non-specific immunity, growth performance, and disease resistance against Edwardsiella tarda in Cirrhinus mrigala.

\section{Materials and Methods}

C. mrigala fingerlings with an average weight of $(10.5 \pm 1.4 \mathrm{~g})$ were procured from Namdev
Fish Farm, Mumbai, India. Fishes were acclimatized under well-aerated conditions in the wet laboratory 1000 L FRP tanks at 25-28 0C fed with a commercial carp diet containing 45\% protein@4\% of their body weight.

\section{Experimental design and diet formulation}

Curcumin was brought from Mark, India. The diets were prepared using ingredients such as Corn flour, Soya flour, fish meal, wheat flour, cellulose, cod liver oil, vitamin and mineral mixture premix etc. The required ingredients were mixed to form dough with the addition of a necessary quantity of water and the same was cooked. The steamed dough was then completely cooled. In various concentrations the vitamins and mineral mixture along with curcumin were added and six experimental diets were made as $\mathrm{C}(0.0 \%), \mathrm{T} 1(0.25 \%), \mathrm{T} 2$ (0.5\%), T3 (1.0\%), T4 (1.5\%), and T5 (2.0\%) (Manju, Vijayasree, Akbarsha and Oommen 2013) as listed in table 1 . The pellets were prepared and dried properly before use. After drying, pellets were packed in polyethylene bags, sealed airtight and labeled. The feed having $(43 \%)$ crude protein, $(11 \%)$ lipid and $(36 \%)$ carbohydrate were prepared. $C$. mrigala fingerlings $(\mathrm{n}=360)$ of mean weight (10.5 g \pm 1.4$)$ were randomly distributed into 18 tanks to form six experimental groups in triplicate following a completely randomized design (CRD). The fish were fed with the experimental diet to satiation for 45 days. The physicochemical parameters of water were maintained optimum during the experimental period.

\section{Sampling}

Six fishes were sampled from each treatment group on the 0th day (before feeding trial), 15th, 30th and 45th day and the blood were collected with and without anticoagulant. Blood without anticoagulant was allowed to clot for $2 \mathrm{~h}$ for the separation of serum. It was 
then centrifuged at $4500 \mathrm{rpm}$ for $5 \mathrm{~min}$. Serum and plasma were collected and stored at $-80{ }^{\circ} \mathrm{C}$ for further analysis.

\section{Growth parameters}

Fish $(n=5)$ were weighed biweekly from different treatment groups. The growth performance of fish was evaluated in terms of percentage weight gain (\%), feed conversion ratio (FCR), feed efficiency ratio (FER), specific growth rate (SGR), and protein efficiency ratio (PER) using the following formulae:

Weight gain $(\%)=(\mathrm{FW}-\mathrm{IW}) \times 100 / \mathrm{IW}, \mathrm{FCR}=$ Feed gain (DW)/body weight gain (WW), $\mathrm{FER}=1 / \mathrm{FCR}, \mathrm{SGR}(\%)=[\ln (\mathrm{FW})-\ln (\mathrm{IW}) / \mathrm{N}]$ $\times 100$ and $\mathrm{PER}=$ body weight gain $(\mathrm{WW}) /$ crude protein fed. Where $\mathrm{FW}=$ final weight, $\mathrm{IW}=$ initial weight, $\mathrm{DW}=$ dry weight, $\mathrm{WW}=$ wet weight gain, $\ln =$ natural $\log$ and $\mathrm{N}=$ number of cultural days.

\section{Non-specific immune parameters}

Nitroblue tetrazolium assay (NBT) was done following the method of Secombe (1992). The lysozyme activity level was measured using the turbidimetric assay following Sankaran and Gurnani (1972), hen egg white lysozyme (Sigma) taken as standard. Phagocytic activity was detected using Staphylococcus aureus (Hi-Media Mumbai, India) as described by Siwicki and Anderson (1994). Total myeloperoxidase (MPO) content present in serum was estimated according to Quade and Roth (1997). Using total protein kit (Merck, India) Serum protein was estimated by biuret and BCG dye binding following the method of Reinhold (1953). Albumin was estimated by Bromo cresol green binding method developed by Doumas, Watson and Biggs (1971) using albumin kit (Merck, India). Globulin was calculated by subtracting albumin values from total serum protein values. Immunoglobulin plasma was separated by precipitation with polyethylene glycol (PEG) as described by Anderson and Siwicki (1995).

\section{Edwardsiella tarda lethal dose 50 (LD50) estimation}

E. tarda (ATCC 15947) was cultured in $5 \mathrm{ml}$ BHI broth at $28^{\circ} \mathrm{C}$ and centrifuged at 5000 $\mathrm{rpm}$. The pellet was dissolved in $5 \mathrm{ml}$ sterile PBS (pH 7.3). Separately $9 \mathrm{ml}$ of sterile PBS was dispensed into 10 sterile tubes. To the first tube, $1 \mathrm{ml}$ of neat and clean culture $E$. tard $a$ was added and the contents were mixed thoroughly. $1 \mathrm{ml}$ inoculum of the first tube was then transferred to the next tube and serial dilution was done. This procedure was repeated up to the last tube. $0.1 \mathrm{ml}$ of sample from each of the dilution was inoculated to sterile Petri plates containing BHI agar and incubated at $28^{\circ} \mathrm{C}$ for $16-18$ hrs. Plates having 30-300 round tiny cream colonies were selected for counting by using the formula and expressed as CFU per ml.

The number of bacteria was calculated as follows:

$\mathrm{CFU} / \mathrm{ml}=$ No. of colonies $\times$ Reciprocal of dilution factor $\times 10$

6 fishes in each group (six groups) were administered with $100 \mu \mathrm{l}$ of different dilutions of the bacteria ranging from $1 \times 10^{3}$ to $1 \times 10^{7}$ intra-peritoneally into each treatment using $1 \mathrm{ml}$ tuberculin syringe. One group was injected with PBS ( $\mathrm{pH} \mathrm{7.3)} \mathrm{and} \mathrm{was} \mathrm{taken} \mathrm{as}$ control. Mortality was recorded daily for $72 \mathrm{~h}$ and the mortality that occurred post $12 \mathrm{~h}$ was counted and subsequently, the LD50 value was calculated by using the method of Reed and Muench (1938).

\section{Challenge test}

E. tarda (ATCC 15947) was cultured in nutrient broth (Himedia) at $370 \mathrm{C}$ for $24 \mathrm{~h}$. 
The cultures were centrifuged at $3500 \mathrm{rpm}$ for 10 min. The supernatant was discarded and the pellets were suspended in phosphate buffered saline (PBS, $\mathrm{pH}$ 7.3). The final bacterial concentration was adjusted to $5.4 \times$ $10^{5} \mathrm{CFU}$ per $\mathrm{ml}$ by serial dilution.

After days 45 days of feeding 5 fishes from each replicate $(n=15)$ were selected for the challenge test. The fishes were injected with the virulent strain of $E$. tarda suspended in

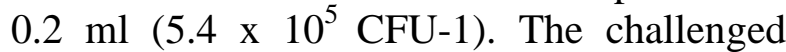
fishes were kept under observation for 14 days and subsequently, RPS was recorded.

\section{Relative percentage survival (RPS) calculation}

Survival was calculated at the end of the 14 days post infection, using the following formula (Amend, 1981)

Relative percentage survival (RPS \%)

$$
\begin{gathered}
\% \text { of mortality fishes after challenge } \\
\% \text { of mortality in control }
\end{gathered}
$$

\section{Statistical analysis}

One way ANOVA was used for the analysis of the raw data and Duncan's multiple range tests were performed to analyze the statistical difference between the treatments. SPSS version 16 was used to perform all the analysis.

\section{Results and Discussion}

\section{Growth performance}

The effect of Curcumin fed diets to the fishes at different levels on the growth performance is presented in table 2. At the end of the experiment period, the highest percent weight gain (PWG) was recorded in treatment $\mathrm{T} 4$
(1.5\% curcumin). FCR was significantly lower $(\mathrm{p}<0.05)$ in treatment T4 $(2.00 \pm 0.11)$ than control group while FER and SGR were significantly higher in T4 compared to control.

\section{Non-specific immune parameters}

The NBT activity (OD at $620 \mathrm{~nm}$ ) among different treatment groups ranged from $0.14 \pm$ 0.01 to $0.18 \pm 0.03$ including control groups (Fig. 1). NBT activity increased significantly ( $p<0.05$ ) with time in fishes fed with different doses of curcumin and the highest activity of NBT was observed in the group fed with $1 \%$ to $1.5 \%$ curcumin supplement $\operatorname{diet}(\mathrm{CSD})$.

Figure 2 shows the Serum lysozyme activity (units/min) of $C$. mrigala during 45 days of feeding in different curcumin treatment groups and control. The results showed the serum lysozyme activity was significantly ( $p$ $<0.05$ ) highest in treatment $\mathrm{T} 4$.

The phagocytic activity (\%) was found to be significantly $(p>0.05)$ higher in different curcumin-fed groups compared to control. The highest phagocytic activity was observed in T3 and T4 curcumin supplemented groups (Fig. 3). The Myeloperoxidase activity (OD at $450 \mathrm{~nm}$ ) of the different treatment groups varied significantly $(\mathrm{p}<0.05)$ and showed an increasing trend from 15 days to 45 days of sampling (Fig. 4). The highest MPO activity was found to be in the treatment $\mathrm{T} 2$ throughout the experiment.

Table 3 shows the levels of serum protein, albumin, globulin and total immunoglobulin of $C$. mrigala during 45 days of feeding trail with treatment and control diets. At the end of 45-day serum protein in T3 $(5.82 \pm 0.39)$ were improved with no significant difference with treatment T4 and T5. Similar results were also observed for globulin in different treatments. 
However, the albumin content was highest in treatment $\mathrm{T} 5(3.12 \pm 0.15)$ on 45 days of sampling. Total immunoglobulin values in treatment group T1 (1.48 \pm 0.07$)$ and T4 (1.53 $\pm 0.20)$ were significantly $(\mathrm{p}<0.05)$ higher with no significant difference than rest of the treatment groups.

\section{LD50 of $E$. tarda}

The first mortality was observed after $24 \mathrm{~h}$ of intraperitoneal injection with E. tarda $1 \times 10^{3}$ CFU / ml. After $72 \mathrm{~h}$ the cumulative percentage mortality was recorded as $1 \times 10^{3}$ (83\%), $1 \times 10^{4}(66 \%), 1 \times 10^{5}(50 \%), 1 \times 10^{6}$ $(33 \%)$ and $1 \times 10^{7} \quad(16 \%)$ respectively. However, intraperitoneal injection with PBS ( $\mathrm{pH} 7.3$ ) in control group shows no mortality (Table 4). In the current study, it was determined that for $C$. mrigala the lethal dose (LD50-72h) of E. tarda was recorded as $5.4 \times 10^{5} \mathrm{cfu} / \mathrm{ml}$. The E. tarda was re-isolated from dead fish by dissecting the internal organ (Kidney) for further confirmation in SS- agar (Fig. 5 and plate 1).

\section{Challenge study}

The experimental fish in each group was challenged with the LD50 dose of $5.4 \times 10^{5}$ $\mathrm{CFU} /$ fish by intraperitoneal injection.

Mortality was recorded twice a day for 14 days. Accordingly, the RPS in the different treatment groups post challenge were calculated and the highest RPS was recorded in T4 $(62.5 \%)$ followed byT2 $(50 \%)$ respectively (Table 5).

It is a well-known fact that the supplementation of the dietary bioactive compounds such as immunostimulants and probiotics improves the growth, immunity performance and resistance to infections (Ramasamy et al., 2011).

Fig.1 NBT activity under different treatments fed with various levels of curcumin in C. mrigala during different sampling days. Values are mean \pm SE. Mean values with different superscript for a parameter is significantly different, $(\mathrm{p}<0.05)$

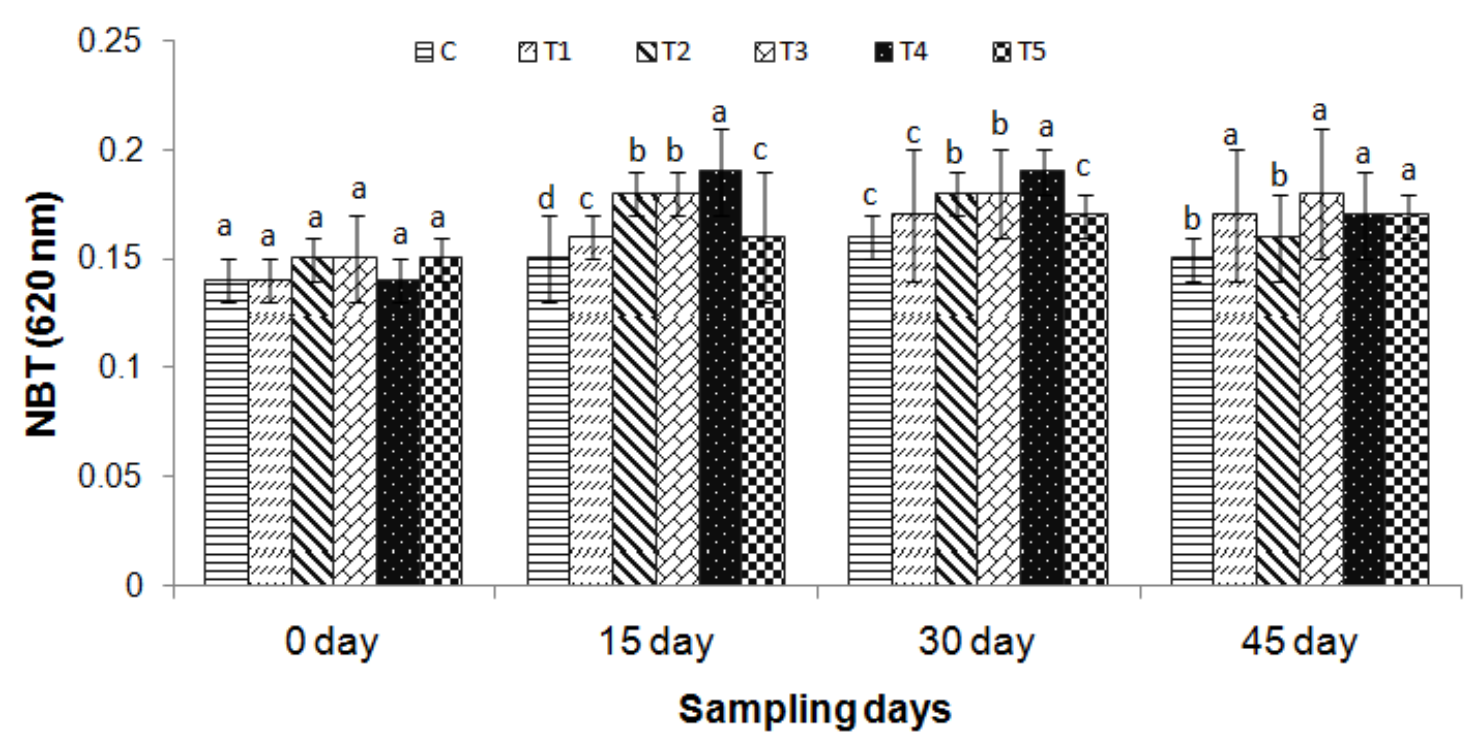


Fig.2 Serum lysozyme activity under different treatments fed with various levels of curcumin in C. mrigala during different sampling days. Values are mean \pm SE. Mean values with different superscript for a parameter is significantly different, $(p<0.05)$

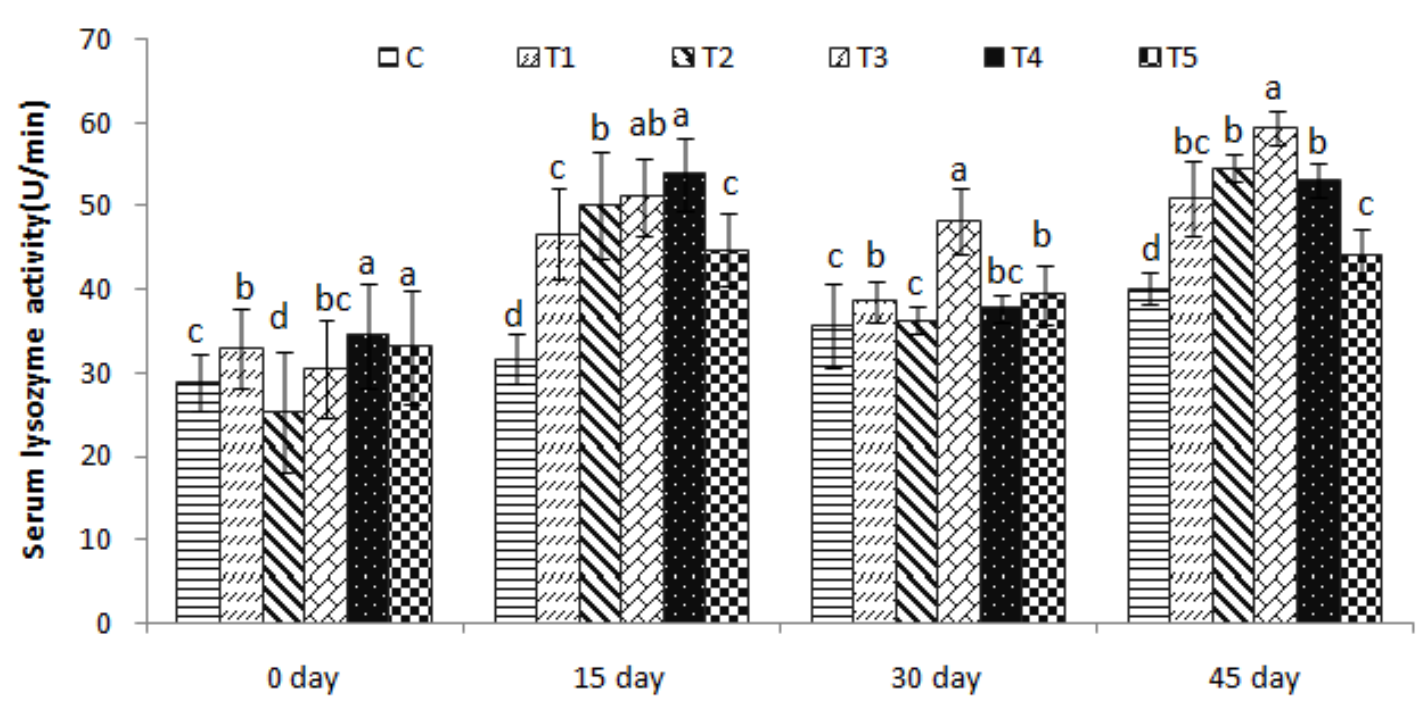

Fig.3 Phagocytic activity under different treatments fed with various levels of curcumin in $C$. mrigala during different sampling days. Values are mean \pm SE. Mean values with different superscript for a parameter is significantly different, $(\mathrm{p}<0.05)$

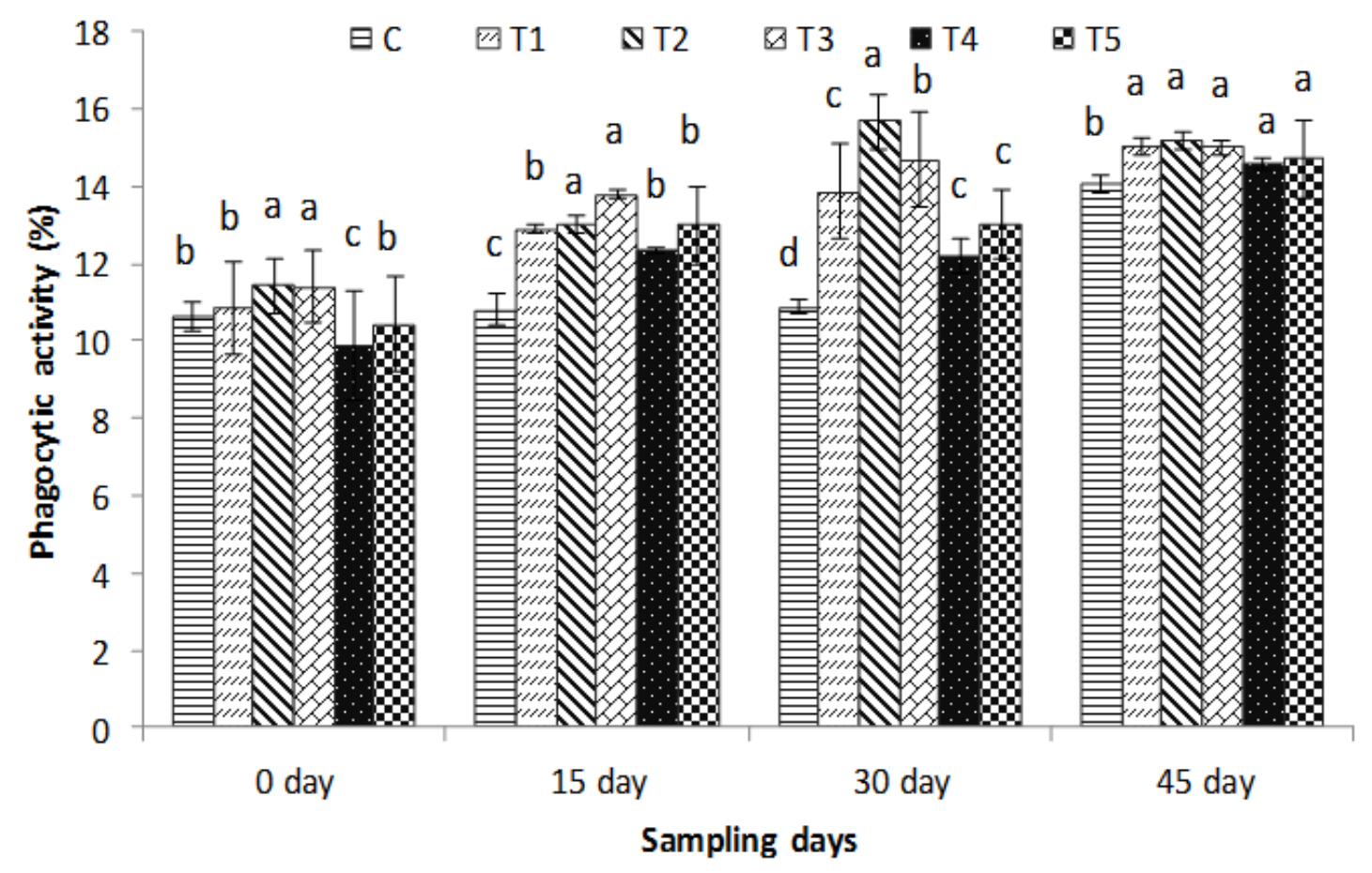


Fig.4 Myloperoxidase activity (MPO) under different treatments fed with various levels of curcumin in $C$. mrigala during different sampling days. Values are mean \pm SE. Mean values with different superscript for a parameter is significantly different, $(\mathrm{p}<0.05)$

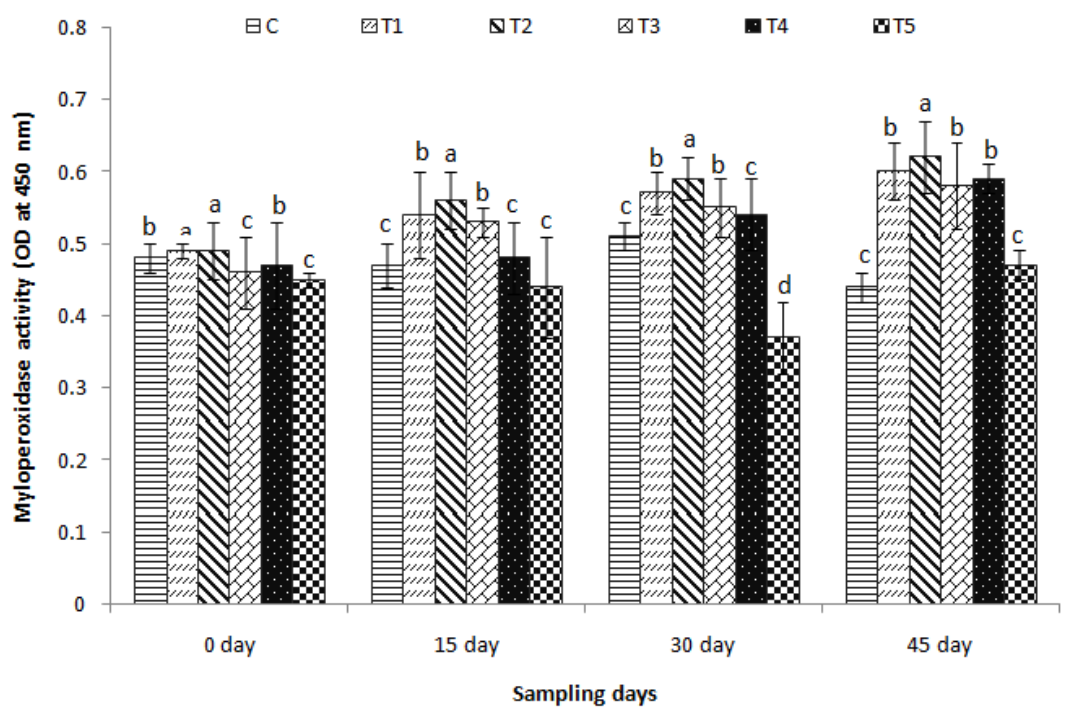

Fig.5 Clinical sign of E.tarda infected mrigal fish

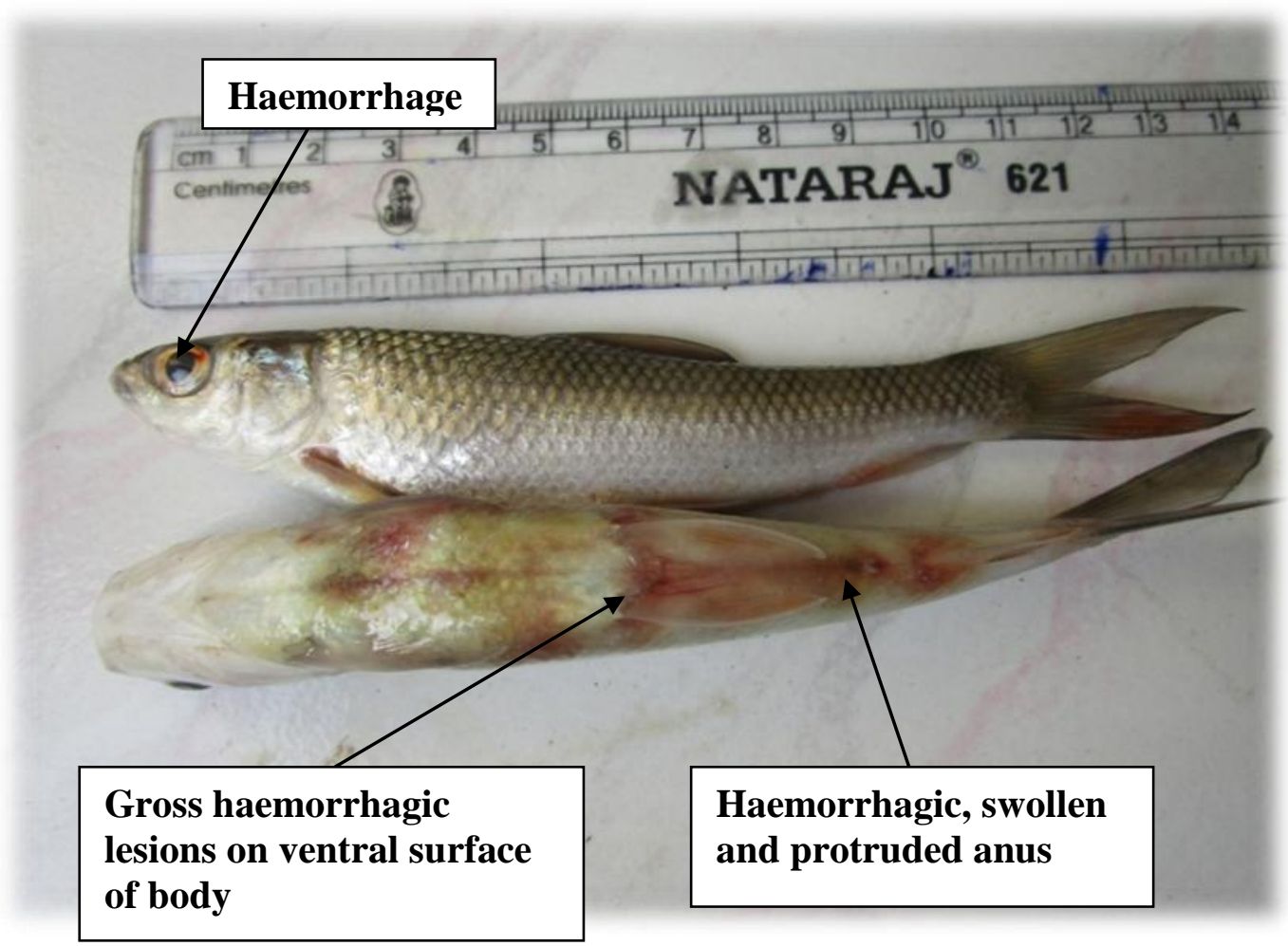


Plate.1 E. tarda colonies on SS agar varied from 1-3mm diameter and showed small black centers to predominantly black colonies indicating $\mathrm{H}_{2} \mathrm{~S}$ production

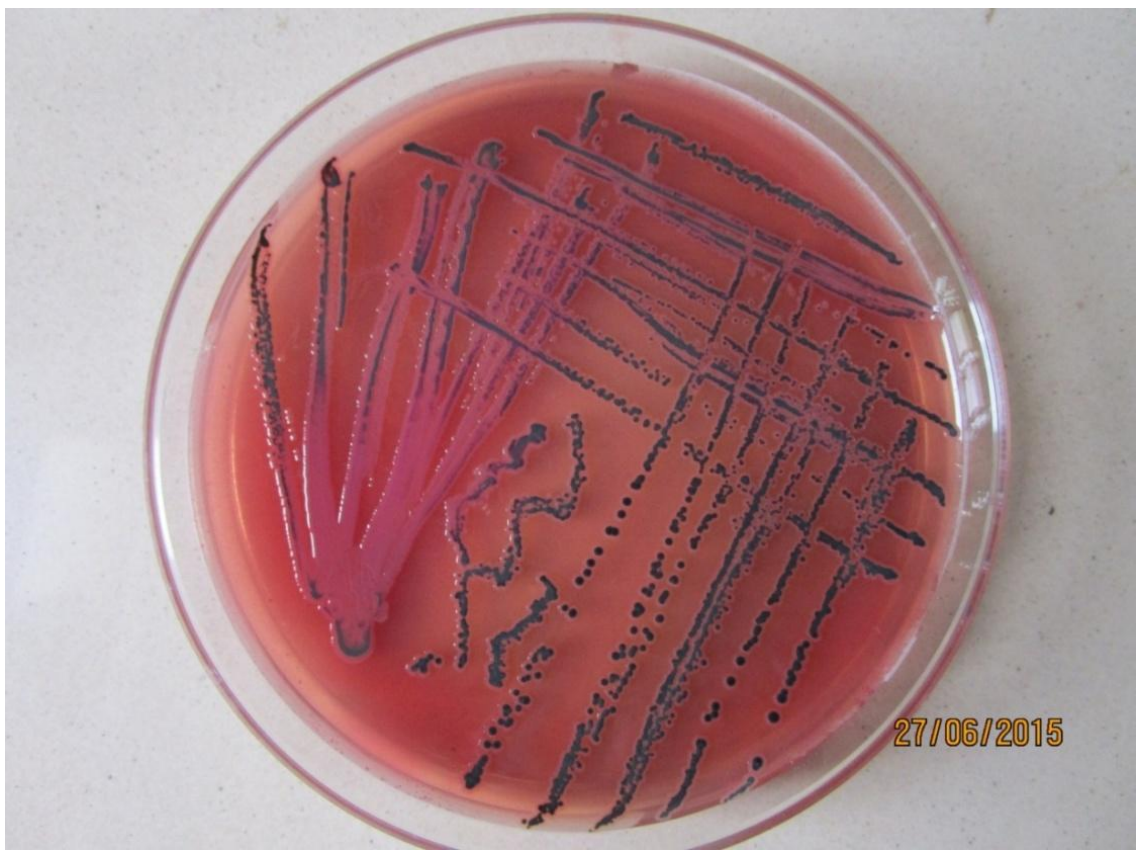

Table.1 Formulation of experimental diets (in 100 grams)

\begin{tabular}{lllllll}
\hline Ingredients (g) & Control & T1 & T2 & T3 & T4 & T5 \\
\hline Fish meal & 25 & 25 & 25 & 25 & 25 & 25 \\
Soya flour & 32 & 32 & 32 & 32 & 32 & 32 \\
Corn flour & 12 & 12 & 12 & 12 & 12 & 12 \\
Wheat flour & 15 & 15 & 15 & 15 & 15 & 15 \\
Cellulose & 6 & 5.5 & 5 & 4.5 & 4 & 3.5 \\
CMC & 2 & 2 & 2 & 2 & 2 & 2 \\
Vegetable oil & 6 & 6 & 6 & 6 & 6 & 6 \\
Vitamin and Mineral & 2 & 2 & 2 & 2 & 2 & 2 \\
premix & & & & & & 2.0 \\
Curcumin & 0 & 0.25 & 0.5 & 1.0 & 1.5 & \\
\hline
\end{tabular}

Composition of Vitamin-mineral mix (Agrimin) (Quantity $\mathrm{kg}^{-1}$ ), Vitamin A-6,25,00 IU; Vitamin D3- 62,500 IU; Vitamin E- 250 mg; Nicotinamide-1 g; Cu-312 mg; Co- 45 mg; Mg- 6 g; Fe- 1.5 g; Zn-2.13 g; I- 156 mg; Se- 10 mg; Mn- 1.2 mg; Ca- 247.34 g; P- 114.68 g; S- 12.2 g; Na- 5.8 mg; K- 48.05 mg.

Table.2 Effect of curcumin fed diet on the growth performance of C. mrigala

\begin{tabular}{lllllll}
\hline Parameter & Control & T1 & T2 & T3 & T4 & T5 \\
\hline IW $(\mathrm{g})$ & 12.30 & 12.57 & 12.57 & 12.21 & 12.30 & 12.50 \\
FWG $(\mathrm{g})$ & 16.70 & 16.63 & 17.00 & 15.77 & 17.47 & 17.77 \\
PWG $(\%)$ & $35.79^{\mathrm{b}} \pm 1.16$ & $32.37^{\mathrm{b}} \pm 1.24$ & $35.44^{\mathrm{b}} \pm 5.64$ & $39.17^{\mathrm{a}} \pm 0.08$ & $42.10^{\mathrm{a}} \pm 2.63$ & $37.14^{\mathrm{b}} \pm 3.00$ \\
FCR & $2.36^{\mathrm{abc}} \pm 0.07$ & $2.19^{\mathrm{bc}} \pm 0.06$ & $2.35^{\mathrm{bc}} \pm 0.02$ & $2.00^{\mathrm{c}} \pm 0.18$ & $2.00^{\mathrm{c}} \pm 0.11$ & $2.74^{\mathrm{a}} \pm 0.05$ \\
FER & $2.12^{\mathrm{d}} \pm 0.06$ & $2.19^{\mathrm{bc}} \pm 0.06$ & $2.34^{\mathrm{c}} \pm 0.312$ & $2.70^{\mathrm{a}} \pm 0.177$ & $2.60^{\mathrm{b}} \pm 0.109$ & $2.31^{\mathrm{c}} \pm 0.049$ \\
SGR & $1.43^{\mathrm{abc}} \pm 0.03$ & $1.35^{\mathrm{bc}} \pm 0.03$ & $1.42^{\mathrm{abc}} \pm 0.13$ & $1.57^{\mathrm{c}} \pm 0.09$ & $1.58^{\mathrm{ab}} \pm 0.08$ & $1.21^{\mathrm{a}} \pm 0.03$ \\
\hline
\end{tabular}

Note: IW= Initial weight; FWG = final weight gain; PWG = percent weight gain; FCR =feed conversion ratio; $\mathrm{FER}=$ feed efficiency ratio; SGR = specific growth rate; Values in the same column with different superscripts letters are significantly different $(P<0.05)$. Values are presented as mean \pm SEM $(n=5)$. 
Table.3 Non-specific immune parameters in C. mrigala fed with curcumin

\begin{tabular}{|c|c|c|c|c|c|}
\hline Parameter & Treatment & O day & 15 day & 30 day & 45 day \\
\hline \multirow[t]{6}{*}{ Protein $(\mathrm{mg} / \mathrm{dl})$} & Control & $2.58^{\mathrm{a}} \pm 0.17$ & $2.47^{\mathrm{b}} \pm 0.38$ & $3.88^{\mathrm{d}} \pm 0.66$ & $4.33^{\mathrm{b}} \pm 0.56$ \\
\hline & $\mathrm{T} 1$ & $2.57^{\mathrm{a}} \pm 0.12$ & $3.03^{\mathrm{a}} \pm 0.42$ & $5.21^{\mathrm{b}} \pm 0.87$ & $5.52^{\mathrm{b}} \pm 0.20$ \\
\hline & $\mathrm{T} 2$ & $2.61^{\mathrm{a}} \pm 0.42$ & $2.53^{\mathrm{b}} \pm 0.04$ & $4.71^{\mathrm{c}} \pm 0.55$ & $4.98^{\mathrm{b}} \pm 0.10$ \\
\hline & $\mathrm{T} 3$ & $2.85^{\mathrm{a}} \pm 0.56$ & $3.17^{\mathrm{a}} \pm 0.45$ & $6.23^{\mathrm{a}} \pm 0.76$ & $5.82^{\mathrm{a}} \pm 0.39$ \\
\hline & $\mathrm{T} 4$ & $2.42^{\mathrm{a}} \pm 0.31$ & $2.58^{\mathrm{b}} \pm 0.15$ & $6.50^{\mathrm{a}} \pm 0.53$ & $5.57^{\mathrm{a}} \pm 0.21$ \\
\hline & T5 & $2.35^{\mathrm{a}} \pm 0.48$ & $2.93^{\mathrm{a}} \pm 0.45$ & $4.93^{\mathrm{c}} \pm 0.55$ & $5.77^{\mathrm{a}} \pm 0.11$ \\
\hline \multirow[t]{6}{*}{ Albumin (mg/dl) } & Control & $1.02^{\mathrm{b}} \pm 0.11$ & $1.21^{\mathrm{c}} \pm 0.20$ & $2.17^{\mathrm{c}} \pm 0.11$ & $2.86^{\mathrm{b}} \pm 0.01$ \\
\hline & $\mathrm{T} 1$ & $1.13^{\mathrm{b}} \pm 0.06$ & $1.20^{\mathrm{b}} \pm 0.18$ & $2.75^{\mathrm{b}} \pm 0.09$ & $3.26^{\mathrm{b}} \pm 0.21$ \\
\hline & $\mathrm{T} 2$ & $0.98^{\mathrm{b}} \pm 0.16$ & $1.17^{\mathrm{b}} \pm 0.12$ & $3.09^{\mathrm{b}} \pm 0.05$ & $3.23^{\mathrm{b}} \pm 0.06$ \\
\hline & $\mathrm{T} 3$ & $1.07^{\mathrm{b}} \pm 0.10$ & $1.20^{\mathrm{b}} \pm 0.03$ & $2.59^{\mathrm{b}} \pm 0.10$ & $2.97^{\mathrm{b}} \pm 0.10$ \\
\hline & $\mathrm{T} 4$ & $1.06^{\mathrm{b}} \pm 0.05$ & $1.89^{\mathrm{b}} \pm 0.14$ & $3.20^{\mathrm{b}} \pm 0.13$ & $3.07^{\mathrm{b}} \pm 0.24$ \\
\hline & T5 & $1.04^{\mathrm{a}} \pm 0.18$ & $1.92^{\mathrm{a}} \pm 0.16$ & $2.62^{\mathrm{a}} \pm 0.16$ & $3.12^{\mathrm{a}} \pm 0.15$ \\
\hline \multirow[t]{6}{*}{ Globulin (mg/dl) } & Control & $0.69^{\mathrm{a}} \pm 0.12$ & $0.52^{\mathrm{c}} \pm 0.08$ & $1.70^{\mathrm{d}} \pm 0.27$ & $1.47^{\mathrm{d}} \pm 0.24$ \\
\hline & $\mathrm{T} 1$ & $0.93^{\mathrm{a}} \pm 0.08$ & $1.05^{\mathrm{a}} \pm 0.17$ & $2.46^{\mathrm{b}} \pm 0.39$ & $2.26^{\mathrm{c}} \pm 0.16$ \\
\hline & $\mathrm{T} 2$ & $0.86^{\mathrm{a}} \pm 0.13$ & $0.91^{\mathrm{b}} \pm 0.09$ & $1.62^{\mathrm{d}} \pm 0.29$ & $1.76^{\mathrm{d}} \pm 0.16$ \\
\hline & T3 & $0.91^{\mathrm{a}} \pm 0.17$ & $0.86^{\mathrm{b}} \pm 0.25$ & $2.48^{\mathrm{b}} \pm 0.26$ & $2.85^{\mathrm{a}} \pm 0.35$ \\
\hline & $\mathrm{T} 4$ & $0.74^{\mathrm{a}} \pm 0.16$ & $0.69^{\mathrm{c}} \pm 0.08$ & $2.95^{\mathrm{a}} \pm 0.35$ & $2.50^{\mathrm{b}} \pm 0.45$ \\
\hline & T5 & $0.50^{\mathrm{a}} \pm 0.06$ & $1.01^{\mathrm{a}} \pm 0.05$ & $2.31^{\mathrm{c}} \pm 0.26$ & $2.65^{\mathrm{a}} \pm 0.15$ \\
\hline Total & Control & $0.49^{\mathrm{d}} \pm 0.07$ & $0.55^{\mathrm{b}} \pm 0.01$ & $1.14^{\mathrm{c}} \pm 0.12$ & $1.24^{\mathrm{c}} \pm 0.02$ \\
\hline Immunoglobulin & $\mathrm{T} 1$ & $0.56^{\mathrm{cd}} \pm 0.05$ & $0.57^{\mathrm{b}} \pm 0.02$ & $1.56^{\mathrm{ab}} \pm 0.32$ & $1.48^{\mathrm{a}} \pm 0.07$ \\
\hline \multirow[t]{4}{*}{$(\mathrm{mg} / \mathrm{dl})$} & $\mathrm{T} 2$ & $0.76^{\mathrm{bc}} \pm 0.04$ & $0.46^{\mathrm{c}} \pm 0.12$ & $1.63^{\mathrm{a}} \pm 0.24$ & $1.36^{\mathrm{c}} \pm 0.02$ \\
\hline & $\mathrm{T} 3$ & $0.85^{\mathrm{a}} \pm 0.03$ & $0.53^{\mathrm{b}} \pm 0.01$ & $1.48^{\mathrm{b}} \pm 0.17$ & $1.43^{\mathrm{ab}} \pm 0.17$ \\
\hline & $\mathrm{T} 4$ & $0.72^{\mathrm{bc}} \pm 0.01$ & $0.69^{\mathrm{a}} \pm 0.03$ & $1.53^{\mathrm{ab}} \pm 0.27$ & $1.53^{\mathrm{a}} \pm 0.20$ \\
\hline & T5 & $0.82^{\mathrm{a}} \pm 0.13$ & $0.73^{\mathrm{a}} \pm 0.05$ & $0.93^{\mathrm{d}} \pm 0.15$ & $1.31^{\mathrm{c}} \pm 0.06$ \\
\hline
\end{tabular}

The means with no superscript letter in common per factor indicates significant difference. If the effects were significant, ANOVA was followed by Duncan multiple range test. $p<0.05$.Values are presented as mean \pm SE.

Table.4 Mortality of $C$. mrigala during the $\mathrm{DL}_{50-72 \mathrm{~h}}$ of Edwardsiella tarda

\begin{tabular}{lllll}
\hline Bacteria concentration (cfu / mL) & $\mathbf{2 4} \mathbf{~ h}$ & $\mathbf{4 8} \mathbf{~ h}$ & $\mathbf{7 2} \mathbf{~ h}$ & Mortality \% \\
\hline $\mathrm{PBS}(\mathrm{pH} 7.3)$ & 0 & 0 & 0 & 0 \\
$1 \times 10^{3}$ & 1 & 2 & 2 & 83 \\
$1 \times 10^{4}$ & 0 & 1 & 3 & 66 \\
$1 \times 10^{5}$ & 0 & 1 & 2 & 50 \\
$1 \times 10^{6}$ & 0 & 0 & 2 & 33 \\
$1 \times 10^{7}$ & 0 & 1 & 0 & 16 \\
\hline
\end{tabular}

Table.5 Relative percentage Survival of $C$. mrigala after challenge study with E. tarda

\begin{tabular}{|c|c|c|c|c|}
\hline Treatment & $\begin{array}{l}\text { No. of fish } \\
\text { injected }\end{array}$ & $\begin{array}{l}\text { No. of fish } \\
\text { death }\end{array}$ & $\begin{array}{l}\text { Cumulative } \\
\text { mortality }(\%)\end{array}$ & RPS (\%) \\
\hline Control & 15 & 8 & 53.33 & ---- \\
\hline $\mathrm{T} 1$ & 15 & 5 & 33.33 & 37.5 \\
\hline $\mathrm{T} 2$ & 15 & 4 & 26.67 & 50 \\
\hline $\mathrm{T} 3$ & 15 & 5 & 33.33 & 37.5 \\
\hline $\mathrm{T} 4$ & 15 & 3 & 20.00 & 62.5 \\
\hline $\mathrm{T} 5$ & 15 & 6 & 40.00 & 25 \\
\hline
\end{tabular}

The means with no superscript letter in common per factor indicates significant difference. If the effects were significant, ANOVA was followed by Duncan multiple range test. $p<0.05$. Values are presented as mean \pm SE. 
Immune system stimulation of fishes through novel drugs, especially from plant sources, is of great interest for commercial aquaculture. Keeping in view the above facts the present study evaluates the effect of active compound from turmeric Curcuma longa (curcumin) on growth performance, non-specific immune parameters and disease resistance against E. tarda of C. mrigala.

The present study demonstrates that dietary supplementation with curcumin enhances growth and disease resistance of $C$. mrigala during the experimental period. The results are in agreement with the previous findings of Curcumin, Andrographolide, and ginger extract dietary inclusion has been shown to improve the growth performance of Carassius auratus, Labeo rohita and tilapia (Jiang et al., 2016; Basha et al., 2013; Immanuel et al., 2009).

NBT activity is typically associated with respiratory burst activity, characterized by intracellular localization of super oxide anion in phagocytes (Sahoo et al., 2005). Phagocytes after activation generate super oxides and other reactive compounds (i.e. hydrogen peroxide and hydroxyl radical) during the period of intense oxygen consumption called respiratory burst (Secombes and Fletcher, 1990). These oxygen reactive radicals are considered toxic for bacterial fish pathogens (Hardie et al., 1991). In the present study, the highest activity of NBT was observed in the group fed with $1 \%$ to $1.5 \%$ CSD which was beneficial in protecting them from the disease-causing organism (E. tarda). Other immunostimulant such as $\beta$-glucan (Jeney and Anderson, 1993), chitin (Sakai et al., 1992), azadirachtin (Kumar et al., 2013), garlic (Sahu et al., 2007), Andrographolide (Basha et al., 2013) are also known to stimulate phagocytes in fishes.
It is well known that lysozyme is a primary marker of fish defense system, which causes of lysis of pathogens, activation of the complement system and phagocytes by acting as opsonin (Magnadottir, 2006). Lysozyme is an enzyme that breaks down the peptidoglycan ( $\beta$-1, 4-glycosidic linkages) of the bacterial cell wall thereby controlling the infection. An increase in the lysozyme activity suggests elevation of various humoral factors that protect the host during pathogen invasion (Harikrishnan et al., 2010). It was also previously reported that serum lysozyme activity could be enhanced through dietary administration by various herbs in Chinese sucker (Zhang, Gong, Yu and Yuan 2009) and L. rohita (Das et al., 2015) treated with tulsi (Ocimum sanctum) extracts; in yellow crocker supplemented with Astragalus root (Jian and $\mathrm{Wu}, 2003)$ and $L$. rohita fed with Andrographolide (Basha et al., 2013). In present finding, Serum lysozyme activity was significantly enhanced in fishes fed with curcumin diet in compared to control group. The results showed the serum lysozyme activity was significantly $(\mathrm{p}<0.05)$ highest in treatment $\mathrm{T} 4$ (1.5\%).

Myeloperoxidase (MPO) is considered to be abundantly expressed in neutrophil granulocytes which play an important role in the defense of the organism. MPO is stored in primary, azurophilic granules of neutrophils and having broad bactericidal armamentarium. It utilizes hydrogen peroxide during the respiratory burst to produce hypochlorous acid (Dalmo et al., 1997). In our finding, the treatment groups showed higher MPO activity (except T5) compare to control. A similar agreement was reported in L. rohita fed with levamisole and Allium sativum respectively (Wijendra and Pathiratne, 2007; Sahu et al., 2007)

Serum protein, albumin, and globulin are important factors in immune response enhancement and are thought to be associated 
with stronger non-specific immune responses in fishes (Wiegertjes et al., 1996). In the present study the serum protein, albumin and globulin values in the fishes fed with curcumin supplement diet were significantly higher than control. Similarly, higher total serum protein, albumin, and globulin were observed in Labeo rohita fed with tulsi (Ocimum sanctum) (Das et al., 2013).

Proteins include the humoral elements of the nonspecific immune system, e.g. immunoglobulin, transferrin, agglutinins or precipitins (Magnadottir, 2010). Fish immunoglobulin is a tetrameric molecule and is far for the most prevalent immunoglobulin in plasma (Warr, 1997). The total immunoglobulin level showed a significant increase with a graded increase in the concentration of curcumin up to T4 group. The present finding of higher total immunoglobulin is supported with the findings in greasy groupers (Epinephelus taurine) fed with herbal diet containing purified active component of Ocimum sanctum (Sivaram et al., 2004), Withania somnifera, and Myristica fragrans in Siberian sturgeon, (Acipenser baeri) fed with epin and glucan respectively also reported higher level of total Ig (Kolman et al., 2001). Also in Indian major carp (Labeo rohita) dietary incorporation of Achyranthes aspera, coated feed (Rao et al., 2004) and levamisole (Wijendra et al., 2007), supports the present findings of higher total $\mathrm{Ig}$ in subsequent treatment groups.

Edwardsiellosis is one of the major threats to fish culture (Sahoo and Mukherjee, 2002), which caused heavy mortality in aquaculture farms. In the present study, the highest relative percentage survival (RPS) was recorded in T4 $(62.5 \%)$ followed by T2 (50\%), groups respectively. The T4 and T5 groups showed better performance in terms of overall growth parameter than the control group which is an agreement with previous study conducted in $L$. rohita fed with diet containing herb Achyrathes aspera (Rao et al., 2004) and in P. monodon fed with Solanum tribbatum, Andrographis paniculata and Psoralea corylitolia (Citrasu et al., 2003a). Since fish require a long time to produce antibody, therefore, the decreased mortality rate should be considered mainly due to increased non-specific immunity (Anderson, 1992) as evident from the present study were increased NBT activity, phagocytic activity, lysozyme activity suggesting Curcumin supplement diet (CSD) is responsible for enhancing of humoral immune responsive.

\section{Acknowledgements}

I am very grateful to the Director, ICARCentral Institute of Fisheries Education, Mumbai, India for providing all the equipment facilities and financial support to conduct the present research.

\section{References}

Amend, D.F., 1981. Potency testing of fish vaccines. Fish biologics: serodiagnostic and vaccine.

Anderson, D.P., 1992. Immunostimulants, adjuvants and vaccine carriers in fish: applications to aquaculture. Ann. Rev. Fish Dis, 2: 281-307.

Anderson, D.P., Siwicki AK. 1995. Basic haematology and serology for fish health programs. In: Shariff, M., Arthur., J.R., Subasinghe, R.P., (Eds.). Diseases in Asian aquaculture II. Fish Health Section. Manila: Asian Fisheries Society: Pp. 185202.

Basha, K.A., Raman R P, Prasad K P, Kumar K, Nilavan E, Kumar S. 2013. Effect of dietary supplemented andrographolide on growth, non-specific immune parameters and resistance against Aeromonas hydrophila in Labeo rohita (Hamilton). Fish and shellfish immunology, 35(5): 1433-1441.

Citarasu, T., Raja Jeya Sekar R, Venketramalingam K, Dhandapani P S, Marian M P. 2006. Effect of wood apple Aegle marmelos, Correa (Dicotyledons, Sapindales, Rutaceae) extract as an 
antibacterial agent on pathogens infecting prawn (Penaeus indicus) larviculture. Indian J Mar Sci., 2003a 32(2): 156-161.

Dalmo, R.A., Ingebnghtsen K, Bogwald J. 1997. Non-specific defense mechanisms in fish, with particular reference to the reticuloendothelial system (RES), J. Fish Dis 20: 241-273.

Das, R., Raman R P, Saha H, Singh R. 2015. Effect of Ocimum sanctum Linn. (Tulsi) extract on the immunity and survival of Labeo rohita (Hamilton) infected with Aeromonas hydrophila. Aquaculture Research, 46(5): 1111-1121.

Doumas, B.T., Watson W A, Biggs H G. 1971. Albumin standards and the measurement of serum albumin with bromcresol green. Clinica chimicaacta, 31 (1): 87-96.

Ellis, A.E., 1988. General principles of fish vaccination. Fish Vaccination, Academic Press, London: 20-31.

Ewing, W.H., McWhorter AC, Escobar MR, Lubin AH. 1965. Edwardsiella, a new genus of Enterobacteriaceae based on a new species, $E$. tarda. International Journal of Systematic and Evolutionary Microbiology, 15.1: 33-38.

Grondel, J.L., Nouws, J. F. M., Muiswinkel, W. V. 1987. The influence of antibiotics on the immune system: immuno pharmokinetic investigations on the primary anti- SRBC response in carp, Cyprinus carpio L., after oxytetracycline injection. Journal of Fish Diseases, 10(1), 35-43.

Hardie, L.J., Fletcher, T.C. and Secombes, C.J. 1991. The effect of dietary vitamin $\mathrm{C}$ on the immune response of Atlantic salmon Salmo salar. Aquaculture, 95: 201-214.

Harikrishnan, R., Heo J, Balasundaram C, Kim M C, Kim J S, Han Y J, Heo M S. (2010). Effect of traditional Korean medicinal (TKM) triherbal extract on the innate immune system and disease resistance in Paralichthys olivaceus against Uronema marinum. Veterinary parasitology, 170(1): 1-7.

Immanuel, G., Uma R P, Iyapparaj P, Citarasu T, Punitha Peter S M, Michael Babu M,
Palavesam A. 2009. Dietary medicinal plant extracts improve growth, immune activity and survival of tilapia Oreochromis mossambicus. Journal of fish biology, 74(7): 1462-1475.

Jeney, G., Anderson D P. 1993. Glucan injection or bath exposure given alone or in combination with a bacterin enhances the non-specific defense mechanisms in rainbow trout (Oncorhynchus mykiss). Aquaculture, 116(4): 315-329.

Jian, J., Wu Z. 2003. Effects of traditional Chinese medicine on nonspecific immunity and disease resistance of large yellow croaker, Pseudosciaena crocea (Richardson). Aquaculture, 218(1): 1-9.

Jiang, J., Wu, X.Y., Zhou, X.Q., Feng, L., Liu, Y., Jiang, W.D., Wu, P. and Zhao, Y. 2016. Effects of dietary curcumin supplementation on growth performance, intestinal digestive enzyme activities and antioxidant capacity of crucian carp Carassius auratus. Aquaculture, 463, pp.174-180.

Kolman, H., 2001. The humoral effects of epin in Siberian sturgeon (Acipenser baeri Brandt). Archives of Polish Fisheries, 9(1): 61-69.

Kolman, R., Kolman H, Siwicki R. 1998. The effect of some immunomodulators on the growth rate of sturgeon fry (Acipenseridae). Archives of Polish Fisheries 6(2): 383-390.

Kumar, S., Raman R P, Pandey P K, Mohanty S, Kumar A, Kumar K. 2013. Effect of orally administered azadirachtin on nonspecific immune parameters of goldfish Carassius auratus (Linn. 1758) and resistance against Aeromonas hydrophila. Fish and shellfish immunology 34(2): 564-573.

Magnadottir, B., 2006. Innate immunity of fish (overview). Fish and shellfish immunology 20(2): 137-151.

Magnadottir, B., 2010. Immunological control of fish diseases. Marine biotechnology 12(4): 361-379.

Manju, M., Vijayasree, A. S., Akbarsha, M. A., Oommen, O.V. 2013. Protective effect of 
dietary curcumin in Anabas testudineus (Bloch) with a special note on DNA fragmentation assay on hepatocytes and micronucleus assay on erythrocytes in vivo. Fish Physiol. Biochem 39: 13231330 .

Masuda, T., Toi, Y., Bando, H., Maekawa, T, Takeda, Y. and Yamaguchi, H. 2002. Structural identification of new curcumin dimers and their contribution to the antioxidant mechanism of curcumin. $J$ Agric Food Chem 50: 2524-2530.

Mohanty, B.R., P K Sahoo. (2007). Edwardsiellosis in fish: a brief review. Journal of biosciences 32.3: 1331-1344.

Negi, P.S., Jayaprakasha, G. K., Jagan Mohan Rao, L., Sakariah, K. K. 1999. Antibacterial activity of turmeric oil: a byproduct from curcumin manufacture. Journal of Agricultural and Food Chemistry 47(10), 4297-4300.

Nucci, C., Da Silveira WD,da Silva Correa S, Nakazato G, Bando SY, Ribeiro MA, de Castro AP. 2002. Microbiological comparative study of isolates of Edwardsiella tarda isolated in different countries from fish and humans. Veterinary Microbiology 89.1: 29-39.

Ozaki, K., Kawata, Y., Amano, S., Hanazawa, S. 2000. Stimulatory effect of curcumin on osteoclast apoptosis. Biochemical pharmacology, 59(12), 1577-1581.

Plumb, J.A., Vinitnantharat S, Paterson W D. 1994. Optimum concentration of Edwardsiella ictaluri vaccine in feed for oral vaccination of channel catfish. Journal of aquatic animal health 6(2): 118-121.

Quade, M.J., Roth J A. 1997. A rapid, direct assay to measure degranulation of bovine neutrophil primary granules. Veterinary Immunology and Immunopathology, 58(3): 239-248.

Raa, J., Roerstad, G., Engstad, R., Robertsen, B. 1992. The use of immunostimulants to increase resistance of aquatic organisms to microbial infections. Diseases in Asian Aquaculture, 1, 39-50.

Ramasamy Harikrishnan, Man-Chul Kim, Ju-
Sang Kim, Chellam Balasundaram, Moon-Soo Heo. 2011. Probiotics and herbal mixtures enhance the growth, blood constituents, and nonspecific immune response in Paralichthys olivaceus against Streptococcus parauberis. Fish and Shellfish Immunology, 31: 310-317.

Rao, P.S.S., Lim T M, Leung K Y. 2001. Opsonized virulent Edwardsiella tarda strains are able to adhere to and survive and replicate within fish phagocytes but fail to stimulate reactive oxygen intermediates. Infection and immunity, 69(9): 5689-5697.

Rao, Y.V., Das BK, Pradhan J, Chakraborti R. 2001. Effect of Achyranthes asperaon the immunity and survival of Labeo rohita infected with Aeromonushydrophila. Fish shellfish Immunol, 20: 263-73.

Rao, Y.V., Romesh M, Singh A, Chakrabarti R. 2004. Potentiation of antibody production in Indian major carp Labeo rohita, rohu, by Achyranthes asperaas a herbal feed ingredient. Aquaculture, 238(1): 67-73.

Reed, L.J., Muench H. 1938. A simple method of estimating fifty per cent endpoints. American Journal of Epidemiology, 27(3): 493-497.

Reinhold, J.G., 1953. Standard methods of clinical chemistry. $1: 88$.

Rijkers, G.T., Teunissen, A. G., Van Oosterom, R., Van Muiswinkel, W. B. 1980. The immune system of cyprinid fish. The immunosuppressive effect of the antibiotic oxytetracycline in carp (Cyprinus carpio L.). Aquaculture, 19(2), 177-189.

Sahoo, P.K., Kumari J, Mishra B K. 2005. Nonspecific immune responses in juveniles of Indian major carps. Journal of Applied Ichthyology 21(2): 151-155.

Sahoo, P.K., Mukherjee S C. 2002. The effect of dietary immunomodulation upon Edwardsiella tarda vaccination in healthy and immunocompromised Indian major carp (Labeo rohita). Fish and Shellfish Immunology12 (1): 1-16.

Sahu, S., Das B K, Mishra B K, Pradhan J, 
Sarangi N. 2007. Effect of Allium sativum on the immunity and survival of Labeo rohitainfected with Aeromonas hydrophila. Journal of Applied Ichthyology 23(1): 80-86.

Sakai, M., Kamiya H, Ishii S, Atsuta S, Kobayashi M. 1992. The immunostimulating effects of chitin in rainbow trout, Oncorhynchus mykiss. Diseases in Asian Aquaculture 1: 413417.

Sankaran, K., Gurnani S. 1972. On the variation in the catalytic activity of lysozyme in fishes. Indian journal of biochemistry and biophysics 9(2): 162-165.

Secombes, C.J., 1990. Isolation of salmonid macrophages and analysis of their killing activity. Techniques in fish immunology, 1: $137-154$.

Secombes, C.J., Fletcher T C. 1992. The role of phagocytes in the protective mechanisms of fish. Annual Review of Fish Diseases, 2:53-71.

Sivaram, V., Babu M M, Immanuel G, Murugadass S, Citarasu T, Marian M P. 2004. Growth and immune response of juvenile greasy groupers (Epinephelus tauvina) fed with herbal antibacterial active principle supplemented diets against Vibrio harveyiinfections. Aquaculture, 237(1): 9-20.

Siwicki, A.K., Anderson D P, Rumsey G L. 1994. Dietary intake of immunostimulants by rainbow trout affects non-specific immunity and protection against furunculosis. Veterinary Immunology and Immunopathology, 41 (1): 125-139.
Surh, Y.J., Chun, K.S., Cha, H.H., Han, S.S., Keum, Y.S., Park, K.K. 2001. Molecular mechanisms underlying chemopreventive activities of anti-inflammatory phytochemicals: down-regulation of COX-2 and iNOS through suppression of NF-Kappa B activation. Mutat Res., 481: 243-268.

Thune, R.L., Stanley L A, Cooper R K. 1993. Pathogenesis of gram-negative bacterial infections in warm water fish. Annual Review of Fish Diseases, 3: 37-68.

Warr, G.W., 1997. The adaptive immune system of fish. Dev. Biol. Stand, 90: 1521.

Wiegertjes, G.F., Stet RJM, Parmentier HK, Van Muiswinkel WB. 1996. Immunogenetics of disease resistance in fish; a comparable approach. Dev. Comp. Immunol, 20: 365-381.

Wijendra, G.D.N.P., Pathiratne A. 2007. Evaluation of immune responses in an Indian carp, Labeo Rohita (Hamilton) fed with Levamisole incorporated diet. J. Sci. Univ. Kelaniya, 3: 17-28.

Yano, S., M. Terai, K. L. Shimizu, T. Sekine, Y. Yamamoto, K. Takamoto, K. Saito, K. Ueno, K. Watanabe. 2000. Antiallergic activity of Curcuma longa (I) Effectiveness of extracts containing curcuminoids. Nat. Med., 54: 318- 324.

Zhang, G., Gong S, Yu D, Yuan H. 2009. Propolis and Herba Epimedii extracts enhance the non-specific immune response and disease resistance of Chinese sucker, Myxocyprinus asiaticus. Fish and Shellfish Immunology, 26(3): 467-472.

\section{How to cite this article:}

Tasok Leya, Ram Prakash Raman, Prem Prakash Srivastava, Kundan Kumar, Irshad Ahmad, Adnan Hussain Gora, Nalini Poojary, Saurav Kumar and Showkat Ahmad Dar. 2017. Effects of Curcumin Supplemented Diet on Growth and Non-Specific Immune Parameters of Cirrhinus mrigala against Edwardsiella tarda Infection. Int.J.Curr.Microbiol.App.Sci. 6(9): 1230-1243. doi: https://doi.org/10.20546/ijcmas.2017.609.149 